\title{
The 2.0 Marketing Strategies for Wine Tourism Destinations of Excellence
}

\author{
Paola Scorrano \\ University of Salento, Lecce, Italy
}

\begin{abstract}
The aim of this paper is to empirically research the use of Web 2.0 applications in the communication strategies of wine tourism destinations of excellence; main attention will be focused on the integration of these tools within the "official” destination websites. The main research questions are: (1) Do wine tourism destinations of excellence worldwide make use of Web 2.0 tools in their official websites? (2) Is it possible to estimate the degree of intensity of use of such tools? The method used for the purpose of this research is inductive: starting from the observation of some specific cases we wanted to implement a scoring model that, taking into account the presence and intensity of the use of Web 2.0 tools selected by the wine tourism destinations of excellence, could be replicated in different contexts from the one analyzed here. The study reveals the interest in the tools of Web 2.0 by the institutional bodies responsible for management of destinations; however it also shows that there is not a full awareness of the scope of strategic and organizational development in the web 2.0 applications resulting in the relationship with potential visitors and those who have already experienced a tourist territory.
\end{abstract}

Keywords: wine tourism, Web 2.0, social network, destination management

\section{Introduction and Objectives}

The Web 2.0 is a digital revolution that has changed and continues to change the way to use the network by millions of users around the world and, above all, creates real transformations in the intensity, in the forms and the ways of people networking. The distinguishing features of Web 2.0 applications are the shared participation, the "open source" logic and the creation of network of users (O'Reilly, 2006). These are to be considered "revolutionary" aspects, since they brought a new "social mission" characterized by the creation and maximization of the collective intelligence of the participants, expression which means that knowledge is produced and distributed within a group ("The interactive exchange of information and the continuous development and maintenance of a group opinion is described as the process of collective intelligence”. Hogg, Meckel, Stanoevska-Slabeva, \& Martigninoni, 2006).

In the last few years, the development of network tools such as Blogs or online Social Networks ${ }^{1}$ have given the opportunity to users, as never before, to inter relate and adopt means of contact, exchange and sharing

Paola Scorrano, Assistant Professor of Economics and Management, Faculty of Economics, University of Salento.

Correspondence concerning this article should be addressed to Paola Scorrano, Faculty of Economics “A. de Viti-de Marco”, University of Salento, via per Monteroni, Complesso Ecotekne, 73100 Lecce (Italy). E-mail: paola.scorrano@unisalento.it.

${ }^{1}$ Among the various Web 2.0 applications, social media assume a specific importance in fostering networking processes and can be divided into two main categories: social media and social media collaborative expression. The first is the social network that allows users to create, produce, share information and content through specific application (this category includes blogs, Twitter, YouTube, Facebook, photo sharing sites like Flickr and other social networking sites) ; collaborative social media, e.g., Wikipedia are open source software that allow a potentially infinite number of users to collaborate on content creation and generation of ideas. 
(Epifani, 2007; Kotler, Kartajaya, \& Setiawan, 2010; Rosato \& Scorrano, 2011). Hence there has been a transition from an elite based web usage to a commonly shared one (Prati, 2007). Remarkably, the power of this new communication tool lies not only in the possibility for many to share a significant amount of information (in real-time), but also to participate in the genesis of this information and share it. The value of information sharing is as high to the users as higher is the number of participants to the same network, since everybody updates it through their own experiences (Scorrano, 2008). It recalls in this regard the Metcalfe's Law that "the utility that has a network for a single user is equal to the square of the number of network users” (Downes \& Mui, 1998).This means that the value of the Internet and information produced by it grows exponentially with the number of users, using technology, are provided with the information it provides.

The Web 2.0 tools are therefore able to wipe off the traditional richness/reach trade-off typical of the real economy (Valdani, 2000), where richness is the variety of information (precision), the ability to customize it according to the users needs (customization), the amount of information that can be traded at any given time (width), the ability of recipients to interact with the information provider (interactivity) and the guarantee of the reliability of the information; where reach is the connectivity, i.e., the number of people who can access information with the above features via the web tools. In the old economy a high degree of richness comes with a low degree of reach, i.e., the availability of extensive, customized and reliable information allowing a dialogue between provider and recipient is only able to reach a rather small target (and vice versa). The Web 2.0 tools, allow an infinite number of users to interact independently and with the business, having access to a high quantity of information on different subjects via the net.

Tourism is one of the fastest developing sectors in the Web, it has been ranked as the most important sector in terms of on-line transaction volumes; in fact internet is the communication channel most used by public and private tourism organizations (Werthner \& Ricci, 2004; Akehurst, 2008).

The 2.0 tourism can be defined as "the business revolution in the tourism and leisure industry caused by the move to the tourist ecosystem as platform, and an attempt to understand the rules for success on that new platform. Chief Among those rules is this: Build business and destinations that harness network effects to get more productive the more people and business participate in them. Thus, harnessing collective intelligence” (William \& Perez, 2008 ).

Buhalis (2003) states that e-tourism is a consequence of the digitalization of all processes and chains of value in the tourism sector such as travel, hospitality and catering, and is based on the use of strategic ICT applications.

Many aspects are common to tourism and the internet (think about the fragmentation of supply and the potential to sell it globally - Rossi, 2006), first of all the intangible nature of the product which is highly information intensive. In the tourism sector, in fact, the information exchange is very important because the sale object (the trip) is not physically available in the store at the time of purchase. Given this characteristic, the "travelling package" may be properly placed within the cognitive products because "given its complex structure, it needs to offer a non-trivial cognitive experience to the final purchaser” (Mattiacci, Ceccotti, \& De Martino, 2006). Hence the main role of internet in providing information about pricing, availability, and characteristics of individual services, and the adoption the of Web 2.0 tools to access recommendations and travel experiences 
from other users.

The present work is intended to verify the extent of use of 2.0 Web applications in the communication strategies of the so called locations of excellence for wine tourism. Attention will be focused on the integration of such tools as part of the official web sites of these destinations.

\section{Web 2.0 and the Tourism Sector}

As already stated in the above paragraph tourism products are easy to sell over the net given their distinctive intangible nature which contributes to the abatement of logistic costs (Pencarelli, 2003). For these reasons, the tourism sector has been deeply transformed by the advent of computer technology: if we think about the CRS (Computerized Reservation System) in the seventies, the GDS (Global Distribution System) in the Eighties and the Internet Revolution in the second half of the Nineties that allowed to create, develop and globalize the access of basic tourist services through the travel agencies, acting as third parties which had exclusive access to computerized reservation systems. Internet technology has extended these opportunities to the final consumer, redefining and expanding the business system options in the distribution channel of tourism products. Traditionally, the Internet was used to search for hours, find information and to compare prices or to book travel products base (Pencarelli, Betti, \& Forlani, 2005); today, thanks to these new social networking tools people can create their own journey, following the advice of friends and examples of network (facebook) they've posted photos of his tour on Flickr or your videos on youtube, follow the example of digital opinion leaders who have recounted their experience of traveling on your own blog (Forlani, 2009). Today the internet and online services are an essential part of the organization of a trip, whether it is for research and information purposes or for booking (Pencarelli, 2003).

Currently, the major developments are represented by the online Web 2.0 and User Generated Content (UGC) that deeply modify the traditional logic of relationship marketing (Ferrero, 1992), stimulating and enhancing key horizontal relationships of “collaborative marketing” (Kotler, Kartajaya, \& Setiawan, 2011).

Although experts have conflicting opinions about the impact of UGC in the tourism sector ${ }^{2}$, the prevailing belief is that the importance of Web 2.0 can not be ignored for the survival of tourism enterprises (Cox, 2007; O’Connor, 2008; Schegg, Liebrich, \& Scaglione, 2008) ${ }^{3}$.

In this regard the social networks, facilitating interactivity, not only promote the formation of communities of users who have the ability to generate and share content, but are also generators of image of the destination, through which we can get an idea of the overall general opinion of the researched target. According to some

\footnotetext{
${ }^{2}$ Frommer (2007) is skeptical about the effectiveness of UGC because of lack of travel expertise held by the majority of individuals who contribute to the generation of such content.

${ }^{3}$ The social networking tools have, thus, side by side (a little 'gradually undo the effect) tools to intermediaries such as travel agencies, brochures, tour operators, leaflets, mass media in general, the views of friends and relatives. So consumers can find themselves personally and the information necessary for their travel needs, using a wide range of Internet tools like search engines (e.g., Google), destination management systems (such as visitbritain.com), social networks and web portals 2.0 (such as TripAdvisor, Facebook, Twitter, want to know what Atrapalo, holiday, Orkut), price comparators sites (like Expedia, Kelkoo, trivago), photo sharing sites (like Flickr), software applications for tourist phones, GPS , iPhone (like Foursquare), interactive guides (like tripwolf) sites Q \& A (= Question and Answer as Traveller and Mygola), etc. Nasti, Y. (2001, march). Tripadvisor.com e destinazione Sicilia: un'indagine nel mondo del travel 2.0. Osservatorio Turistico Regione Siciliana, Assessorato Turismo Sport e Spettacolo.
} 
scholars (Echtner \& Ritchie, 2003), the flow of information absorbed by the visitor allows the imaging of the target destination, or the development of a mental construct based on a few impressions from this stream. This process, according to the model of Gunn, includes seven steps: (1) organic image (accumulation of mental images on the travel experience); (2) induced image, amended by additional information from promotional sources; (3) decision to make the journey; (4) route to a destination; (5) Experience the target destination; (6) heading back home; (7) Alteration of the organic and induced images of travel destination based on own travel experience (Echtner \& Ritchie, 2003).

The tourism market is now characterized by the so called micro-markets or niches (Dall'Ara \& Santino, 2004) where the micromedia (social networks, blogs, etc..) become a place of informal socialization, information and consulting, therefore turning into filters (Anderson, 2007) capable of conveying important tourist flows.

Web 2.0 offers many promotional opportunities to the local tourist systems particularly with reference to specific market niches. In order to be efficiently operating, these need to be part of a more complex destination management (defined as "a set of strategic decisions, organizational and operational through which to manage the process of defining, promoting and marketing of tourism products expressed from a territory, in order to generate incoming tourism"-Martini, 2005; Caroli, 2006; Ejarque, 2003; Franch, 2002; Pechlaner \& Weiermair, 2000; Sainaghi, 2006; Pike, 2004; Bellagamba, Brunetti, Pencarelli, \& Vigolo, 2007) or destination marketing strategy and must be implemented by established and reliable tourism or local systems (Forlani, 2009). Consider, in particular, the destination management system (DMS), i.e., integrated information systems that collect all the information about a specific destination centrally, highlighting services and factors of attractiveness, and making them accessible for promotion and marketing through a website (Martini, 2000). The development of sites maintained by local tourist organizations (national or regional) can therefore offer new and easy reservation management tools, as alternatives to the traditional travel agency channel (Smith, 2006).

\section{Wine Tourism and the Web}

According to the ninth annual report of the Observatory on wine tourism "The advanced form of communication through the web (social networking, Web 2.0) is an essential investment to be realized in the near future in order to achieve sensitive development results in food and wine tourism. The big meetings of the communication sector (wine exhibitions) are considered to be less effective than direct activities that agencies and tour operators can undertake” (Taiti, 2011).

The e-tourism is in stable growth and is becoming one of the leading sectors of e-commerce and global social media and mobile technologies play an increasingly important role in the procurement processes, by providing access to information in real time, and by facilitating the exchange of experiences ${ }^{4}$.

In Italy, the highest share of Internet commerce is occupied by the tourism sector, which covers more than $50 \%$

\footnotetext{
4 " $\mathrm{n}$ the USA, about $52 \%$ of the 152 million adult leisure travellers-or some 79 million people - already use social media. They represent an attractive customer segment generating \$ 102.9 billion for the domestic US tourism sector compared to \$69.5 billion from non-social media users. Their greater impact is driven by a higher average number of trips (5.4 per year vs. 4.2), although they spend less per trip on average. A high $41 \%$ of US online leisure travellers have become 'travel social fans' (TSFs), signing up as friends, fans or followers of travel suppliers on social networking sites”. IPK international. ITB world travel trends report 2010/2011. Prepared on behalf of ITB Berlin.
} 
of the total, with sales equal to 3.4 million in 2010 (Osservatorio eCommerce B2c Netcomm-School of Management Politecnico di Milano (2011). It comes out that 20 million Italians claim to have carried out some activities related to wine tourism and gastronomy, even though not considering themselves wine experts, 2.6 million define themselves explicitly wine tourists, mainly adult males, living in the center and in the north part of Italy; there are other two million people who claim they have never had experience of wine and food tourism, however they have plans to visit wineries and vineyards, streets and museums of wine in the future (Taiti, 2010).

Wine locations are to be the reference point for a vast amount of tourists looking for experiences focused on the senses, the authenticity, the rediscovery of the roots of the tradition and atmosphere of the place. These areas have a rich heritage of elements to exploit and enhance. The wine acts as a support tool a catalyst of attention in the strategy of customer engagement with the aim of attracting tourists in search of a certain lifestyle that is promoted through the experiencing the identity of a territory, the transmission of word of mouth. Here the Web 2.0 tools are a key promoting factor in digital channel.

During the European Forum “Roads of Wine and Local Economic Development”, held in Cagliari in June of 2011, sponsored by the Cities of Wine, in collaboration with the Department of Agriculture of Sardinia, interesting information on the trend of 'wine tourism and the use of Web 2.0 technologies in some of the main European destinations were discussed. Magda Antonioli Corigliano, special adviser to the EU Commissioner for Tourism, stated that "the current situation shows a substantial growth of communication media (guides, magazines, directories, exhibitions, events). A very advanced penetration of the 'mobile technology': more than $40 \%$ of those who have a smart phone, use it to find information on the destination”.

In France, where 5,000 cellars host 1,500 people on average each year (for a total of about 7 million visitors), the internet is now an essential tool for the wine tourist. "In our country, said Alain Parenteau from the French Tourist Office, the internet is growing steadily, and it is the main role of agencies and tour operators to bring order into the confusion of information found on the web”.

In Spain, in the Duero Rioja, there are about 6 million wine tourists that move along the 21 wine routes across the country, Monica Figuerola Martin, general director of tourism in the region, one of the most popular wine areas in Spain said that "The success of Web 2.0 has confirmed the interest in the sector to communicate and exchange information and opinions. Our website, which recorded over two million visitors in 2010, offers a wide variety of information and suggestions regarding food and wine of the region”.

The importance of the web in tourism is confirmed by the Report No. 9 by the Observatory on Wine Tourism in Italy, prepared by City of Wine and Censis Services, according to which 30\% of wine tourists arrange their holidays through the internet.

And since the "market” via the Internet is constantly growing by double digits (2 billion users worldwide with $+444 \%$ of users from 2000 to 2010) and tourism is one of the most significant items, those offering food and wine tourism must necessarily reflect the need to strengthen their "virtual image”.

\section{The Empirical Investigation}

\section{The Research Methodology}

The aim pursued by the empirical investigation presented in this paper is to attempt to determine empirically 
the use and the procedures of Web 2.0 by wine tourism destinations of excellence worldwide.

In particular, we focused our analysis in depth on the official websites (i.e., those related to official bodies responsible for promoting the destination) of those destinations (that have been identified through an empirical survey carried out earlier; for the methodology adopted in that survey and any other information see Scorrano, 2011) to understand the use of instruments of social network by agencies to promote the area in order to intercept navigators and increase business opportunities.

It was considered useful to check the level of integration achieved between the "traditional" web tools (the website) and the most innovative digital communication tools (Web 2.0) as this may allow the institutions responsible for promoting wine tourism in the territory to control, at least in part, and guide the information circulating on social networking sites (Franch, 2010). This enables these agencies to limit-as far as possible-the effects of loss of control over their communication which the Web 2.0, if not properly governed, can lead to (Customer Managed Relationship) (Law, Lau, \& Wong, 2003).

To achieve the goal set out earlier, we implemented a scoring model of the official websites of wine tourism destinations based on two elements (see figure 1):

- The presence of the tools of Web 2.0, the presence of these instruments also according to the level of simplicity in the identification of "social buttons" on the official sites;

- The degree of intensity of use of Web 2.0 tools.

The choice of the above two elements of analysis is based on the assumption that there is not enough to provide users of web 2.0 tools, but it is essential to create conditions that encourage the use (social visibility of the buttons, to stimulate discussion in social networking, video and photos available to view, etc.), to increase sales opportunities of the destination itself.

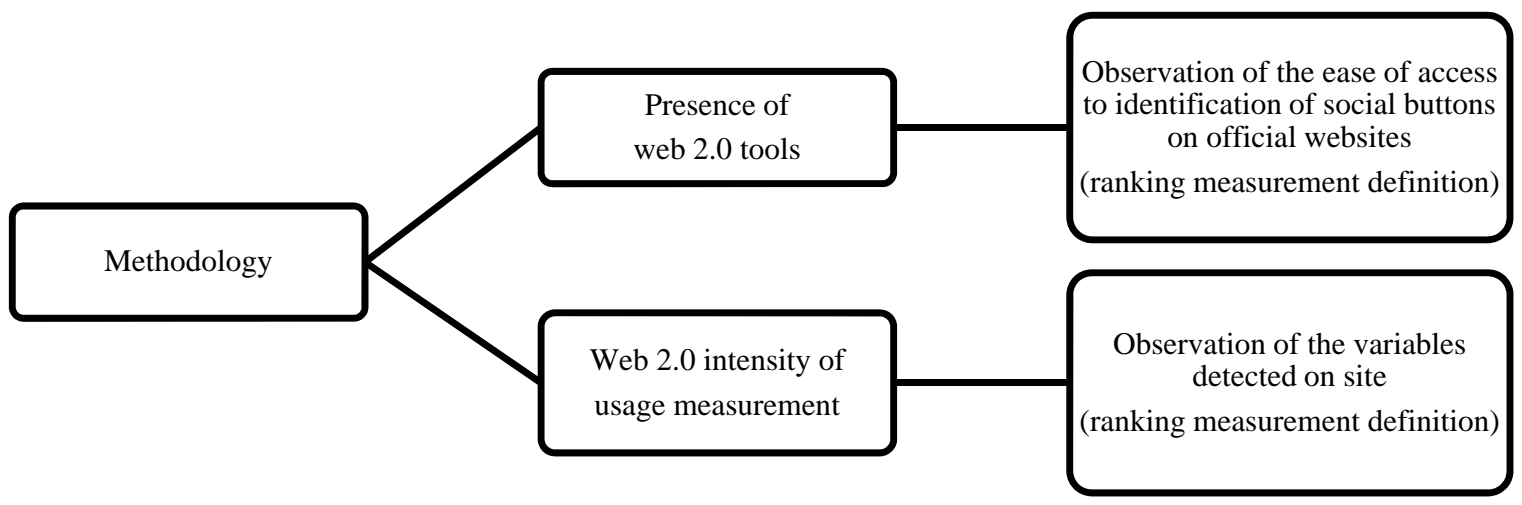

Figure 1. The survey methodology.

The wine tourism destinations examined (whose official tourism websites are presented in Table 2) are: Sonoma Valley (California, USA), Toscana (Italy), La Rioja (Spain), Valle Central (Chile), Bordeaux (France), Barossa Valley (Australia), Piemonte (Italy), Napa Valley (California-USA), Marlborough (New Zealand), 
Champagne Ardenne (France), Umbria (Italy), Stellenbosch (South Africa) ${ }^{5}$.The tools of web 2.0 analyzed are: Facebook, Twitter, YouTube and Flickr that are well known globally (Facebook for social interaction, Twitter to disseminate information via short text messages, YouTube sharing videos and Flickr for photo sharing).

Taking into account the specific functions of each of the above social media, we focused our observations on those variables, specific to each one of these channels, i.e., For Facebook is the number of fans, the number of text messages for Twitter tweets, for YouTube is the number of subscribers, the number of videos uploaded and the number of views, the number of users for Flickr as well as members to the group and the number of items published (see Figure 2).

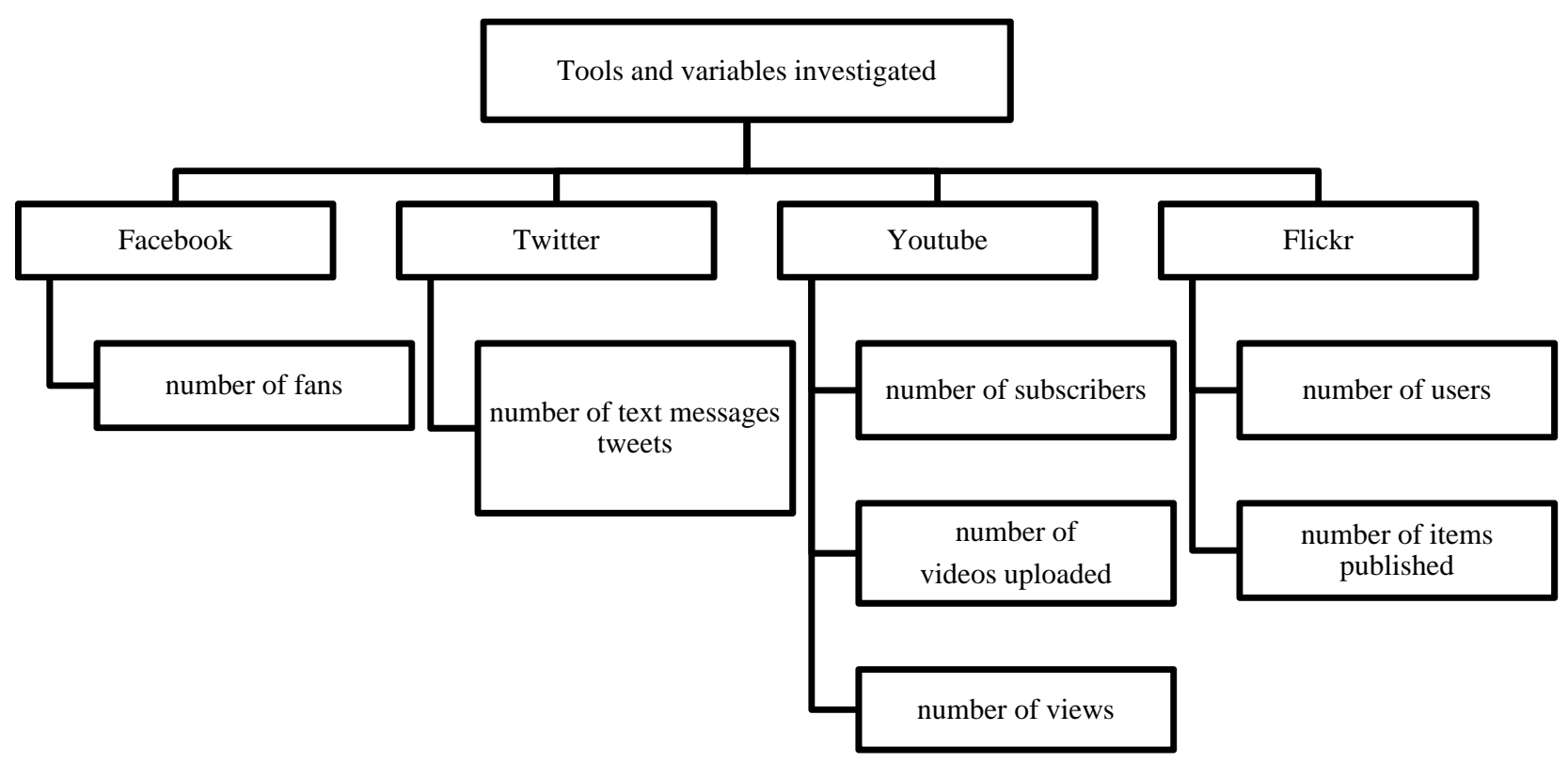

Figure 2. Tools and variables investigated.

To standardize the information and compare similar data, we assigned scores between 0 and 10, in relation to pre-established scoring tables, to represent the largest use made by any territory in question of the examined social networking tools.

For the scoring and, therefore, the preparation of the final ranking we took a step by step approach:

- Identification of the four instruments of social networking sites on the analyzed web site ${ }^{6}$ and allocation of a score of 2.5 for each tool (scale between 0 and 10);

- Weighing a score as reported above according to the ease of accessibility to the social buttons on the website.

\footnotetext{
${ }^{5}$ It is clear that the wine tourism destinations considered relate to geographic areas that have different dimensional characters (some destinations are regions, other cities). We wondered if it would be conceptually correct to compare them with reference to the intensity of use of Web 2.0 applications since it may seem almost obvious that the larger areas can boast a greater "intensity" of use of social networks. In fact, the analysis showed as Champagne-Ardenne (which is a region of France) is not on its official website even while Bordeaux 2.0 web application (which is a city in France) has integrated all four the above tools.

${ }^{6}$ Please note that this survey was conducted during the first week of August 2011.
} 
In particular, starting from the home page, we measured the number of pages to navigate before having access to the social button (it is assumed that the display of each page of the score would entail a reduction of $10 \%$ - as reported above);

- Estimate the degree of intensity in the use of Web 2.0 tools adopting the scoring shown in Table 1 for each variable of each analyzed tool; averaging them for the final scoring (scale of 0 and 10$)^{7}$.

Table 1

Weights Assigned to Examined Variable

\begin{tabular}{|c|c|c|c|c|c|c|c|}
\hline \multicolumn{2}{|c|}{$\begin{array}{l}\text { Weights Facebook } \\
\text { (variable: number of fans) }\end{array}$} & \multicolumn{2}{|c|}{$\begin{array}{l}\text { Weights Twitter (variable: } \\
\text { number of text messages tweets) }\end{array}$} & \multicolumn{2}{|c|}{$\begin{array}{l}\text { Weights Youtube (variable: } \\
\text { number of subscribers) }\end{array}$} & \multicolumn{2}{|c|}{$\begin{array}{l}\text { Weights Youtube (variable: number } \\
\text { of videos uploaded and the number } \\
\text { of views) }\end{array}$} \\
\hline Over 25,000 & 10 & Over 2,500 & 10 & Over 100 & 10 & Over 50 & 10 \\
\hline $25,000-20,000$ & 9 & $2,500-2,000$ & 9 & $100-80$ & 9 & $50-40$ & 9 \\
\hline $20,000-16,000$ & 8 & $2,000-1,600$ & 8 & $80-60$ & 8 & $40-30$ & 8 \\
\hline $16,000-12,000$ & 7 & $1,600-1,300$ & 7 & $60-50$ & 7 & $35-40$ & 7 \\
\hline $12,000-8,000$ & 6 & $1,300-1,000$ & 6 & $50-40$ & 6 & $30-35$ & 6 \\
\hline $8,000-5,000$ & 5 & $1,000-700$ & 5 & $40-30$ & 5 & $25-30$ & 5 \\
\hline $5,000-3,000$ & 4 & $700-500$ & 4 & $30-20$ & 4 & $20-25$ & 4 \\
\hline $3,000-2,000$ & 3 & $500-300$ & 3 & $20-10$ & 3 & $20-15$ & 3 \\
\hline $2,000-1,000$ & 2 & $300-100$ & 2 & $10-5$ & 2 & $15-10$ & 2 \\
\hline Less than 1,000 & 1 & Less than 100 & 1 & Less than 5 & 1 & Less than 10 & 1 \\
\hline Not present & 0 & Not present & 0 & Not present & 0 & Not present & 0 \\
\hline \multicolumn{2}{|c|}{$\begin{array}{l}\text { Weights Youtube (variable: } \\
\text { number of views) }\end{array}$} & \multicolumn{2}{|c|}{$\begin{array}{l}\text { Weights Flickr } \\
\text { (variable: number of users) }\end{array}$} & \multicolumn{2}{|c|}{$\begin{array}{l}\text { Weights Flickr } \\
\text { (variable: number of items } \\
\text { published) }\end{array}$} & & \\
\hline Over 200,000 & 10 & Over 200 & 10 & Over 10,000 & 10 & & \\
\hline $140-200,000$ & 9 & $200-80$ & 9 & $10,000-3,000$ & 9 & & \\
\hline $90-140,000$ & 8 & $80-60$ & 8 & $3,000-2,000$ & 8 & & \\
\hline $50-90,000$ & 7 & $60-50$ & 7 & $2,000-1,500$ & 7 & & \\
\hline $30-50,000$ & 6 & $50-40$ & 6 & $1,500-1,000$ & 6 & & \\
\hline $15-30,000$ & 5 & $40-30$ & 5 & $1,000-700$ & 5 & & \\
\hline \multicolumn{8}{|c|}{ (Table 1 continued) } \\
\hline \multicolumn{2}{|c|}{$\begin{array}{l}\text { Weights Youtube (variable: } \\
\text { number of views) }\end{array}$} & \multicolumn{2}{|c|}{$\begin{array}{l}\text { Weights Flickr } \\
\text { (variable: number of users) }\end{array}$} & \multicolumn{2}{|c|}{$\begin{array}{l}\text { Weights Flickr } \\
\text { (variable: number of items } \\
\text { published) }\end{array}$} & & \\
\hline $15-7,000$ & 4 & $30-20$ & 4 & $700-500$ & 4 & & \\
\hline $7-3,000$ & 3 & $20-10$ & 3 & $500-200$ & 3 & & \\
\hline $3-1,000$ & 2 & $10-5$ & 2 & $200-50$ & 2 & & \\
\hline Less than 1,000 & 1 & Less than 5 & 1 & Less than 50 & 1 & & \\
\hline Not present & 0 & Not present & 0 & Not present & 0 & & \\
\hline
\end{tabular}

\section{The Results of the Research}

The survey has revealed a different use of the tools of Web 2.0 by the agencies responsible for promotion of wine tourism destinations of excellence worldwide.

\footnotetext{
${ }^{7}$ Relative to YouTube and Flickr, for which several variables were examined, the value for calculating the final average (relative to all four of the above tools) is derived from the prior average of observed scores of the different variables of each of the two instruments.
} 
Table 2 represents the ranking of the various territories in relation to the different variables examined.

In general there has been considerable attention to the use of social networks by agencies responsible for promotion of wine tourism areas, in fact, except for one (Champagne-Ardennes) all the destinations have Web 2.0 tools on their websites. 7 target destinations have all four instruments examined, only 1 location has three, 2 destinations have two web 2.0 tools and only a single destination has 1 web 2.0. application.

Table 2

The Use of Web 2.0 Tools

\begin{tabular}{|c|c|c|c|c|}
\hline Destinations & Official web site & $\begin{array}{l}\text { Presence of web } \\
2.0 \text { tools (A) }\end{array}$ & $\begin{array}{l}\text { Presence of web } 2.0 \\
\text { tools “weighted" (B) }\end{array}$ & $\begin{array}{l}\text { Web } 2.0 \text { intensity of } \\
\text { usage measurement } \\
\text { (C ) }\end{array}$ \\
\hline Sonoma valley & www.sonomacounty.com & 10.00 & 10.00 & 9.67 \\
\hline Toscana & www.turismo.intoscana.it & 10.00 & 10.00 & 8.00 \\
\hline La rioja & www.lariojaturismo.com & 10.00 & 10.00 & 5.04 \\
\hline Valle central & www.chile.travel & 10.00 & 10.00 & 4.67 \\
\hline Bordeaux & www.bordeaux-tourisme.com & 10.00 & 10.00 & 3.67 \\
\hline Barossa valley & www.barossa.com & 10.00 & 10.00 & 3.25 \\
\hline Piemonte & www.piemonteitalia.eu & 10.00 & 10.00 & 2.33 \\
\hline Napa valley & www.legendarynapavalley.com & 5.00 & 5.00 & 1.58 \\
\hline Marlborough & www.lovemarlborough.co.nz & 7.50 & 7.50 & 0.88 \\
\hline Umbria & www.regioneumbria.eu & 5.00 & 5.00 & 0.63 \\
\hline Stellenbosch & www.stellenboschtourism.co.za & 2.50 & 2.25 & 0.25 \\
\hline Champagne ardenne & www.tourisme-champagne-ardenne.com & 0.00 & 0.00 & 0.00 \\
\hline
\end{tabular}

This result is noticeable even if the rankings will be reconsidered in light of the ease of access to the tools of social networking websites in the sitemap, because it was found that only one destination (Stellenbosch) does not directly show the buttons on the home page to access the social networks.

A different resulted was reported, however, when looking at the intensity of their use, since it emerged from the analysis that the distribution of this variable has a negative asymmetry, i.e., the largest number of destinations takes lower values than the average (3.33); Barossa Valley and Piedmont, which are high in the league for the presence of Web 2.0 tools (with a maximum score of 10), are positioned below the mean for the level of intensity of use (respectively, obtained 3.25 and 2.33). This result seems particularly negative when compared with that achieved by other destinations, like the previous two, who have all four of the tools of Web 2.0 in their websites and reach even with reference to the intensity of use significant results (9.67 Sonoma Valley and Tuscany 8). It can be inferred that in many cases, adopting Web 2.0 tools is the result of a fashion and not of a strategic and commercial step by agencies responsible for promoting the area.

To better show the extent of use of social networks by the examined destinations, we showed the relationship between the ranking of the intensity and the presence of Web 2.0 tools from official web sites (respectively, column C and column A of Table 1).

The results of this index (Table 3 and Chart 1) can be interpreted as:

- A value of 1 is an indicator of the most efficient use of Web 2.0 tools;

- Values between 0.50 and 1 indicate a significant and appropriate use of Web 2.0 tools; 
- Values between 0.20 and 0.50 indicate an average use of Web 2.0 tools;

- Values between 0 and 0.20 indicate a poor use of Web 2.0 tools.

Table 3

Degree of use of social networks

\begin{tabular}{ll}
\hline Destinations & Ratio between intensity of use and presence of web 2.0 tools \\
\hline Sonoma valley & 0.97 \\
Toscana & 0.80 \\
La rioja & 0.50 \\
Valle central & 0.47 \\
Bordeaux & 0.37 \\
Barossa valley & 0.33 \\
Piemonte & 0.23 \\
Napa valley & 0.32 \\
Marlborough & 0.12 \\
Umbria & 0.13 \\
Stellenbosch & 0.11 \\
Champagne ardenne & 0.00 \\
\hline
\end{tabular}

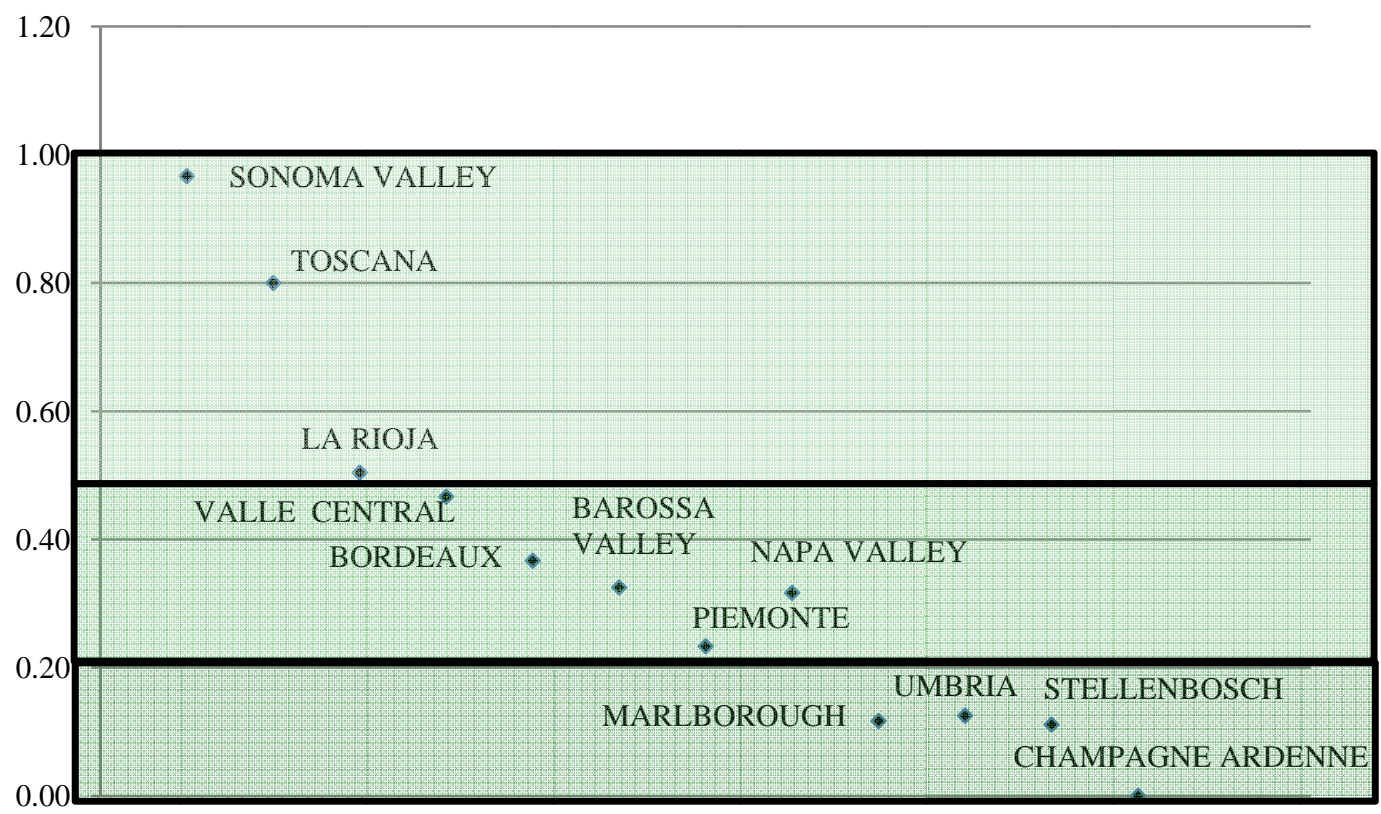

- Ratio between intensity of use and presence of web 2.0 tools

Figure 3. Degree of use of social networks.

Figure 3 highlights that there is a large concentration of territories located in between 0.10 and 0.50 , a result which means that many destinations, although equipped with the tools of Web 2.0, do not exploit their full potential. A note of credit goes to the destinations Sonoma Valley California USA and Tuscany-Italy- for achieving results close to unity. These destinations are distinguished by the following characters (see Table 4). 
Table 4

The First Destinations in the Use of Web 2.0 Tools

\begin{tabular}{lrrc}
\hline Destinations & Average & Sonoma Valley & Toscana \\
\hline Official web site & & www.sonomacounty.com & www.turismo.intoscana.it \\
\hline $\begin{array}{l}\text { WEIGHTS FACEBOOK } \\
\text { (variable: number of fans) }\end{array}$ & 7,721 & 26,862 & 25,513 \\
$\begin{array}{l}\text { WEIGHTS TWITTER } \\
\text { (variable: number of text messages tweets) }\end{array}$ & 1,260 & 4,692 & 1,184 \\
$\begin{array}{l}\text { WEIGHTS YOUTUBE } \\
\text { (variable: number of subscribers) }\end{array}$ & 73 & 99 & 163 \\
$\begin{array}{l}\text { WEIGHTS YOUTUBE } \\
\text { (variable: number of videos uploaded and the number of views) }\end{array}$ & 25 & 59 & 53 \\
$\begin{array}{l}\text { WEIGHTS YOUTUBE } \\
\text { (variable: number of views) }\end{array}$ & 42,260 & 55,354 & 209,119 \\
$\begin{array}{l}\text { WEIGHTS FLICKR } \\
\text { (variable: number of users) }\end{array}$ & 336 & 840 & 51 \\
$\begin{array}{l}\text { WEIGHTS FLICKR } \\
\text { (variable: number of items published) }\end{array}$ & 2,214 & 14,914 & 754 \\
\hline
\end{tabular}

\section{Conclusions}

With this paper we tried to answer two questions:

Do wine tourism destinations of excellence worldwide make use of Web 2.0 tools in their official websites?

Is it possible to estimate the degree of intensity of use of such tools?

The method used for the purpose of this research is inductive: starting from the observation of some specific cases we wanted to implement a scoring model that, taking into account the presence and intensity of the use of Web 2.0 tools selected by the wine tourism destinations of excellence, could be replicated in different contexts from the one analyzed here.

The study on the use of such applications by the terroir of wine worldwide has allowed to observe that although 13 out of 14 destinations examined have at least 2.0 web application, whose buttons of access are clearly visible on the home page of the official website, only a few of them use the marketing 2.0 tools to develop their business in a conscious and efficient way. By observing the results of the relationship between intensity of use and presence of web 2.0 tools, we observed that only two destinations have achieved a result that is greater than 0.50 , that is Tuscany-Italy (index 0.80) and Sonoma Valley US-California (index 0.97).

The study reveals therefore, the interest in the tools of Web 2.0 by the institutional bodies responsible for management of destinations; however it also shows that there is not a full awareness of the scope of strategic and organizational development in the web 2.0 applications resulting in the relationship with potential visitors and those who have already experienced a tourist territory.

The observation of the results and, in particular, the evidence given by Champagne Ardennes, a famous French destination of wine tourism, which did not include any web 2.0 tools within its website, leads to a reflection that could be developed in future research: is it possible to measure the economic effects of the wine tourism destination (eg in terms of increase in turnover achieved in the presence or extended chain) from the application of Web 2.0?

\section{References}

Akehurst, G. (2009). User generated content: the use of blogs for tourism organisations and tourism consumers. Service Business, 3(1). 
Anderson, C. (2007). La Coda Lunga. Da un mercato di massa ad una massa di mercati. Torino: Codice Edizioni.

Bellagamba, A., Brunetti, F., Pencarelli, T., \& Vigolo, V. (2007). La letteratura italiana ed internazionale sul Destination management. In S. Sciarelli (Ed.), Il management dei sistemi turistici locali. Strategie e strumenti per la governance. Torino: Giappichelli.

Buhalis, D. (2003). eTourism: Information technology for strategic tourism management. Harlow: Pearson Education Limited.

Caroli, M. G. (2006). Il marketing territoriale. Strategie per la competitività sostenibile del territorio. Milano: Franco Angeli.

Cox, C., Burgess, S., Sellitto, C., \& Bultjens, J. (2007). Consumer-generated web-based tourism marketing. Australia: CRC for Sustainable Tourism.

Downes, L., \& Mui, C. (1998). Unleashing the Killer App. digital strategies for market dominance. Boston, M.A.: Harvard Business School Press.

Echtner, C. M., \& Ritchie, J. R. B. (2003). The meaning and measurement of destination image. The Journal of Tourism studies, 1.

Ejarque, J. (2003). La destinazione turistica di successo. Marketing e management. Milano: Hoepli.

Franch, M. (2002). Destination Management. Governare il turismo tra locale e globale. Torino: Giappichelli.

Epifani, S. (2007, August). Appunti sul rapporto tra Media e Reti. Retrieved from http://blog.stefanoepifani.it.

Ferrero, G. C. (1992). Il marketing relazionale. L'approccio delle scuole nordiche. Trieste: Ed. Lint.

Forlani, F. (2009). La comunicazione non convenzionale nel turismo. In T. Pencarelli, \& G. L. Gregori (Eds.), Comunicazione e branding delle destinazioni turistiche. Una prospettiva manageriale. Milano: Franco Angeli.

Franch, M. (2010). Marketing delle destinazioni turistiche. Metodi, approcci e strumenti. Milano: Edizione McGraw-Hill.

Giulivi, G. (2001). Il marketing relazionale e comunicazione business to business. Milano: Franco Angeli.

Gummerson, E. (2005). Marketing relazionale. Milano: Hoepli.

Hogg, R., Meckel, M., Stanoevska-Slabeva, K., \& Martigninoni, R.(2006). Overview of business models for Web 2.0 communities. Proceeding of GeNeMe.

Kotler, P., Kartajaya, H., \& Setiawan, I. (2010). Marketing 3.0. Milano: Edizioni Gruppo 24 ore.

Law, M., Lau, T., \& Wong Y. H. (2003). From customer relationship management to customer-managed relationship: unraveling the paradox with a co-creative perspective. Marketing Intelligence \& Planning, 21(1).

Martini, U. (2000). L'impatto di Internet sulla struttura del mercato turistico leisure. Un'analisi comparata nei settori del turismo organizzato e fai-da-te. Trento: Dipartimento di Informatica e Studi Aziendali, Università di Trento.

Martini, U. (2005). Management dei sistemi territoriali. Gestione e marketing delle destinazioni turistiche. Torino: Giappichelli.

Mattiacci, A., Ceccotti, F., \& de Martino, V. (2006). Il vino come prodotto cognitivo: indagine esplorativa sui comportamenti giovanili. Proceedings of 5th International Conference Marketing Trends (J. C. Andreani, \& U. Collesei, Eds.). Paris-Venice: Marketing Trends Association.

Nasti, Y. (2001, March). Tripadvisor.com e destinazione Sicilia: un'indagine nel mondo del travel 2.0.. Osservatorio Turistico Regione Siciliana, Assessorato Turismo Sport e Spettacolo.

O’Connor, O. (2008). User-generated content and travel: A case study on Tripadvisor.com. Information and Communication Technologies in Tourism 2008, Springer Wien, Vienna.

O’Reilly, T. (2006). Web 2.0 principles and best practices. Retrieved from http://www.Oreilly.com/catalog/web2report/chapter/web20_report_excerpt.pdf

Osservatorio eCommerce B2c Netcomm—School of Management Politecnico di Milano (2011, may). L'eCommerceB2c in Italia nel 2011: le prime evidenze dal mercato.

Pechlaner, H., \& Weiermair, K. (2000). Destination Management. Fondamenti di marketing e gestione delle destinazioni turistiche. Milano: Touring University Press.

Pencarelli, T. (2003). Letture di economia e management delle organizzazioni turistiche. Urbino: Edizioni Goliardiche.

Pencarelli, T., Betti, D., \& Forlani, F. (2005). L'attività di ricerca di informazioni per la scelta del prodotto turistico. Sinergie, 66.

Pike, S. (2004). Destination marketing organisations. Oxford: Elsevier.

Prati, G. (2007). Web 2.0. Internet è cambiato. Trento: Uni Service.

Rosato, P., \& Scorrano, P. (2011). Il marketing 2.0 nelle strategie delle imprese vinicole italiane. Proceedings of 10th International Conference Marketing Trends (J. C. Andreani, \& U. Collesei, Eds.). Paris-Venice: Marketing Trends Association.

Rossi, C. (2006). In viaggio... verso il digitale. Le imprese della distribuzione turistica di fronte alla sfida del web. Atti del Congresso internazionale “Le tendenze del marketing”. Venezia, 20-21 gennaio 2006.

Sainaghi, R. (2006). La gestione strategica dei distretti turistici. Milano: CUSL.

Schegg, R., Liebrich, A., Scaglione, M., \& Ahmad, S. F. S. (2008). An exploratory field study of Web 2.0 in Tourism. Information 
and Communication Technologies in Tourism 2008. Springer Wien, Vienna.

Scorrano, P. (2008). Competitività, collaborazione e valore nelle network industries. Un'analisi nel settore dei videogame. Bari: Cacucci.

Scorrano, P. (2011, July 21-23). Wine tourism development of the territory: A comparative analysis of destinations of excellence. Conference Proceedings of Twelfth International Conference of the Society for Global Business \& Economic Development Building Capabilities for Sustainable Global Business: Balancing Corporate Success \& Social Good. Singapore.

Sigala, M. (2011). Enabling sustainable tourism: Virtual exchange networks and marketing tool. Cultural Policy Brief, 5.

Taiti, F. (2010, February). Gli italiani ed il turismo enogastronomico: dalla tribù alle genti. Osservatorio sul Turismo del Vino. VIII Rapporto annuale Prima Parte.

Taiti, F. (2011, March). I nuovi dinamismi di un turismo di tendenza. Osservatorio sul turismo del vino, IX Rapporto annuale. Valdani, E.(2000). L'impresa pro-attiva. Co-evolvere e competere nell'era dell'immaginazione. Milano: McGraw-Hill.

Wang, Y., \& Fesenmaier, D. R. (2006). Identifying the success factors of web-based marketing strategy: An investigation of convention and visitors bureaus in the United States. Journal of Travel Research, 44(3).

Werthner, H., \& Ricci, F. (2004), E-commerce and tourism. Communications of the ACM, 17(12).

William, E., \& Perez, E. (2008). Tourism 2.0. the social web as a platform to develop a knowledge-based ecosystem. Networks and Tourism (online). Retrieved from http://eduwilliam.com/mipdf/Tourism\%202.0\%20_UK_.pdf 